\title{
Discovering Unwritten Stories-A Modular Case Study in Promoting Landscape Education
}

\author{
Shaun Tyan Gin Lim *(D) and Francesco Perono Cacciafoco \\ Linguistics and Multilingual Studies Programme, School of Humanities, Nanyang Technological University, \\ 48 Nanyang Avenue, Singapore 639818, Singapore; fcacciafoco@ntu.edu.sg \\ * Correspondence: L170002@e.ntu.edu.sg
}

Citation: Lim, S.T.G.; Perono

Cacciafoco, F. Discovering Unwritten Stories-A Modular Case Study in Promoting Landscape Education. Educ. Sci. 2021, 11, 68. https:// doi.org/10.3390/educsci11020068

Academic Editor: Alfonso Garcia de la Vega

Received: 26 January 2021

Accepted: 4 February 2021

Published: 9 February 2021

Publisher's Note: MDPI stays neutral with regard to jurisdictional claims in published maps and institutional affiliations.

Copyright: (c) 2021 by the authors. Licensee MDPI, Basel, Switzerland. This article is an open access article distributed under the terms and conditions of the Creative Commons Attribution (CC BY) license (https:/ / creativecommons.org/licenses/by/ $4.0 /)$.

\begin{abstract}
Landscapes have been and are an important aspect of any society, culture, economy and environment. Besides the role of landscape and Landscape Sciences in these arenas, there have been increasingly greater calls to incorporate landscape into the curriculum. Moreover, Landscape Education is beneficial in developing important foundations in students, particularly that of active citizenry. While the benefits of Landscape Education are evident, current research remains focused on Western, especially European, contexts. This article discusses how a leading Singapore public University incorporates Landscape Education within a relatively new module on Toponymy offered in the Linguistics and Multilingual Studies Programme. While the links between Linguistics and a course in Toponymy or even the links between Toponymy and Landscape may not be immediately apparent, an analysis of the content covered in the module demonstrates congruence to existing frameworks and principles in teaching Landscape Education and, at the same time, provides a case in point in interdisciplinarity, drawing from diverse disciplines such as Language, Linguistics, History, Geography, Landscape Sciences, Anthropological Linguistics, among many others. This study provides useful references for educational institutions in incorporating Landscape Education into their curriculum.
\end{abstract}

Keywords: university curriculum; toponymy; linguistics; landscape education; European Landscape Convention (ELC)

\section{Introduction: Landscapes and Landscape Education}

Landscapes are at the core of any society. A 2004 book published by New Zealand's Environmental Defense Society begins with a quote: "Landscapes are a touchstone for where we have come from, who we are and how we relate to the world around us" [1] (p. 2). This quote is significant, given that the book documented the loss of New Zealand's special places to inappropriate subdivision and development and thus highlights how landscapes give people a sense of place and identity. Furthermore, as the quote suggests, landscapes reflect the inter-relationships between people and their environments over the course of history. The intersection between nature and human beings is also evident in the definition provided by the European Landscape Convention (ELC), which was the first international treaty to be exclusively devoted to European landscape. The ELC defines landscape as "an area, as perceived by people, whose character is the result of the action and interaction of natural and/or human factors" [2] (p. 2). This definition, as Dejeant-Pons (2006) argues, is a holistic view and ultimately links the landscape to advancing four elements of sustainable development: nature, culture, society and economy [3].

Beyond the social, cultural, economic and ecological importance of landscape, landscapes also play an important role in the field of education. At the international level, the United Nations Educational, Scientific and Cultural Organization (UNESCO) called for Landscape Science to be one of the key subjects in schools which incorporates sustainability considerations and sustainable development themes [4], a reasonable call given 
how landscape is very much at the heart of physical-human interactions. Moreover, the recommendation of the Committee of Ministers to member states on the guidelines for the implementation of the ELC (2008) reads: "School curricula at various levels should foster an awareness of landscape themes through learning to read landscapes and through sensitization to relations between cadre de vie and landscape, to relations between ecology and landscape problems and to social and economic questions ... Landscape constitutes a teaching resource because, when reading it, pupils are brought face to face with visible signs of their surroundings that relate to spatial-planning issues. Landscape reading also makes it possible to understand current and historical approaches to landscape production as an expression of a community's identity" [5] (p. 13). Certain scholars have also written about the importance of landscapes in education. For instance, Orietta Zanato Orlandini identified three principal functions of landscape in the classroom: (1) the hermeneutical function, where landscapes are read and their signs decoded, (2) the pragmatic function, where students learn to manage, plan and protect the territory and (3) social function, where students develop local identities while opening to "otherness," especially in contexts where there is increased migration [6]. Yet, it must be noted that current research on Landscape Education remain dominated by Euro-Western scholarly sources, ostensibly due to the ELC involving European countries [4,7-12]. In European classrooms, Landscape Education has been weaved into the curriculum through, for example, including content in Social and Natural Sciences subjects which teach students about natural and anthropized landscapes [11]; drawings and questionnaires to get students to recognize the landscapes and around them and subsequently evaluate their views, experiences and feelings towards these landscapes [7,13]; through fieldwork trips to landscape sites [14]; and collaborative learning across multiple Universities, using technologically enhanced learning platforms to critically engage with the theories, methods, ethics and practices of participation in landscape planning [15].

Ultimately, the incorporation of the Landscape into Education promotes engaged and active citizenry. Landscape evolves together with and is shaped by societal changes over the longue durée. Certain studies have shown that Landscape Education, particularly those conducted in outdoor contexts like parks and museums helps students develop empathy to these issues and in the process, become informed and involved citizens [16]. Furthermore, understanding both the physical and human landscapes also foster an awareness and understanding, both in children and adults, on environmental issues, including animal rights ethics [17]. Moreover, with the increased socio-cultural diversity of people living in a territory due to globalization and migration, territorial identities begin to be contested. To this end, Landscape Studies provides a way of navigating these contestations through "opening up an arena for a re-interpretation and adoption of the land" [4] (p. 4704). With the knowledge of landscape formation and evolution, students will be better aware of the risks posed to landscapes and need to preserve them, thereby promoting participation in decision-making $[9,18,19]$.

The present literature on Landscape Education, though scarce, focuses on how European institutions insert landscape into the curricula, along with the benefits which Landscape Education brings. Hence, it would be useful to assess the incorporation of Landscape Education in a non-European context. Consequently, this paper studies the blending of Landscape Education into the curriculum in one of the top public Universities in Singapore. The authors analyze a module on Toponymy offered by the Division of Linguistics and Multilingual Studies. Although the links between Toponymy, Linguistics and Landscapes might not be immediately evident, a close reading of the module's content finds that it enables students to develop an awareness of the landscapes (both in Singapore and overseas contexts) through the study of place names and more crucially, foster an understanding of diachronic and synchronic methods in understanding landscapes and how they contribute to a community's identity, echoing the ELC's proposals as aforementioned.

Therefore, this paper investigates how this new module is a case in point on how Landscape Education can be weaved into the curriculum at university-level relying on a 
holistic, multidisciplinary approach. It conducts an in-depth analysis on the lesson content with the aim of showing how the module draws upon and follows established principles, such as the time-space dimensions in the teaching of Landscape Education as articulated by Antrop and Van Eetvelde and Vos and Meekes [20,21]. Crucially, by introducing students to toponymic examples from around the world and showing how toponyms (and other related disciplines) are linked to landscapes and the way humans conceptualize their environments (thereby lending a regional and international dimension to the course), students then understand and realize how these concepts are related to Singaporean toponymy particularly in the final lesson-a process and observation documented in this paper as well.

The rest of this paper is structured with a short section explaining the links between Toponymy and landscapes, as well as between Toponymy and Linguistics. Thereafter, the authors will provide in greater detail information about the module, entitled Discovering Unwritten Stories: A General Introduction to Toponymy and Toponomastics, before highlighting salient topics and themes covered in the module itself and explaining how it contributes to a Landscape Education in a different context.

\section{Toponymy, Landscapes and Linguistics}

Toponymy is inextricably linked to the landscape, where both nature and humans are concerned. In his 1957 article, Place Names and Geography, the scholar H.C. Darby notes, "To all who travel about the countryside with a glimmer of curiosity and to all who read or even glance at, maps, place-names must always be of great and often of tantalizing, interest. (...) In the same way that (place-names) concern the history of society so they concern the history of landscape, for it was places that were being named and the characteristics of those places are often reflected in their names ... " [22] (p. 387). Place names are regarded as objects of study which have been indelibly influenced by socio-historical factors that shape the natural and human landscapes. These processes of change are then projected onto the place name. Hence, by studying toponyms, one can better understand the history and characteristics of the landscape he/she occupies. Such an endeavor is also aided by Landscape Archaeology which combines archaeological approaches with the study of "how difference (in terms of identities) spreads itself over space and thus to the formation of social landscapes" [23] (p. 19) and covers aspects relating to the symbolic significance of places and how people organize themselves in geographical landscapes as social space [24,25], as well as settlement ecology, ritual landscapes and ethnic landscapes [26]. Toponymy is also shaped by political factors; due to the regime changes and/or shifts in political power, the new leaders thus use place naming and renaming as a means to assert their political authority and mold the landscape according to their socio-political and cultural image. This is observed particularly in post-Communist and neo-liberal contexts [27-29] and even extends to anthropic facilities such as sport stadiums and football clubs [30]. Some scholars have also found that the economic power held by large corporations shaped the landscape in terms of re-naming prominent landmarks bearing the company name of values associated with the organization [31]. Moreover, numerous landscape features are reflected in toponyms. These include the topography and settlement of ethnic groups [32-35], some with a focus on the meaning imputed by local people to their physical and cultural surroundings [36] and migration of people, religious and cultural traditions and local language [37-40]. In sum, the study of toponyms enables one to better understand the landscape, be it the Topography, Geography, History, Society, Culture, Religion or Language.

While Toponymy may not be considered as a "traditional" sub-field of Linguistics, toponyms are still regarded as important linguistic tools. The study of toponyms at the level of Linguistics can be approached using both diachronic and synchronic means. Looking at the names of places diachronically allows linguists to understand the origin and evolution of a place name [41]. This is useful because many toponyms, which remain consistent over time, convey messages about the lives, behaviors, histories and languages 
of the earlier occupants of that place and thereby represents the locality's "collective memory" [42,43]. Toponyms, as carriers of "living heritages" [34], contain numerous linguistic elements and/or naming practices that do not exist in current languages or modern societies. An etymological analysis, using diachronic methods, provides insights on the phonetic, semantic, morphosyntactic and onomasiologic structures of toponyms (and their changes over time). For this reason, the historical linguist Lyle Campbell writes that place names "permit historical inferences about languages and the people who spoke them" in a locality [44]. Historical linguists have thus sought to use place names as clues to lost languages [44], as well as to investigate language contact and language change between different language families in prehistoric contexts [45]. Additionally, from a synchronic perspective, because toponyms are connected to society and history, toponyms represent the linguistic image and history of a place expressed by language features of a particular period [41]. There have also been recent studies that capture the languages and practices used to name toponyms at a certain snapshot of time in the area [46].

Linguistics has also been incorporated into toponymic research as an integral way of studying the biography of a toponym, in a process known as intensive toponymy. Intensive toponymy involves asking wh-questions: (1) Who named the place? (2) When was the place named? (3) Why was it given this name? (4) What does the name mean? What kind of feature is it? (5) Where does the name come from (referring to either the language or region of origin)? Where is the place located? Some of these questions can be answered using linguistic analysis, with the aim of investigating the etymology and meaning of the given toponym. Looking at a toponym's orthographic form(s) (including previous names) and its linguistic fields (such as its morphology, syntax, semantics and etymology) allows us to answer why the place got its name, what the place name means, where the name comes from in terms of the language of origin [47].

While the wh-questions undergirded Tent's paper, prominent linguist and Toponymy scholar Joshua Nash calls for a greater focus on the "how" of Toponymy, a strand of research which considers phenomena between, within and across toponymic contexts and what these contexts mean. To this end, the landscape is used as an object of study, particularly in studying how attributes of landscape vis-à-vis Toponymy and how landscape setting and being in the world shape ways in which individuals develop an attachment to place through place-naming processes and toponyms [48].

In the final analysis, Toponymy as a discipline enables its students and the wider audience to understand the society they live in through multiple angles, including but not limited to Physical, Human, Urban and Historical Geography, Nature, Languages, Linguistics, History, Culture, Society, Landscape Sciences, Landscape Archaeology. It is with this understanding of Toponymy that the authors now describe the module on Toponymy as a case of Landscape Education in the University.

\section{Situating the Module in Landscape Education}

\subsection{An Introduction to HG2093 Discovering Unwritten Stories: A General Introduction to Toponymy and Toponomastics}

HG2093 is a relatively new course offered in the Linguistics and Multilingual Studies Programme (School of Humanities) at Nanyang Technological University, Singapore, institution ranked 13th in the world in the 2020 QS World University Ranking and 1st amongst the world's young Universities according to the QS Top 50 Under 50 rankings [49]. The course has been written, conceptualized, optimized, developed and taught by Dr Francesco Perono Cacciafoco (NTU, SoH, LMS) and was first offered in Semester 2 of the Academic Year 2018/19. Since then, the module has been offered every Semester 2 to Linguistics students, always taught by Dr Perono Cacciafoco. Students can take it to clear Linguistics electives as part of their major. The class size usually averages about 30 to 35 students of Year 1 to Year 4 standing and they attend a weekly three-hour seminar across 13 weeks.

The course description, available on the Division's website, states that students will "become familiar with the basic notions and hermeneutic instruments of Toponymy Studies and Toponomastics, both at the level of language reconstructions (Diachronic Toponymy 
and Historical Toponomastics) and at the historical-cultural and sociological level (Synchronic Toponymy)" as well as provide "indispensable epistemological elements for the understanding of complex notions in Historical Linguistics and Etymology and for the evaluation of the relations between place names and social contexts" [50]. The interdisciplinary nature of the course is also reflected in the learning objectives, highlighted in the syllabus document, that outlines key takeaways that students should achieve upon completing the module. Some of these goals include the abilities to: "Reconstruct the etymological origins and original meanings of place names from all over the world," "Explain the essential role of Historical Toponomastics (the historical analysis of place names) in the study of the origins of languages," "Document toponymic phenomena like the conservatism of place names throughout changes in population and settlement dynamics in a specific area" and "Explain the relations between Toponymy, Toponomastics, Etymology, Language Change, Historical Linguistics, Historical Semantics and Sociolinguistics and the relations between landscape (and the archaeology of landscape) and place names" [51] (p. 2).

\subsection{Course Content, Assessments and Analyses}

From now on, this paper analyses the content and structure of the module as an example to show how Landscape Education is incorporated into the University curriculum in a non-European context. The content covered throughout this module is shown in Table 1.

Table 1. Course content of HG2093 Discovering Unwritten Stories: A General Introduction to Toponymy and Toponomastics.

\begin{tabular}{cc}
\hline Week Number & Topic \\
\hline Week 01 & An Introduction to Toponymy and Toponomastics \\
Week 02 & Toponyms and Toponymic Classification \\
Week 03 & Disputed Place Names and Sequent Occupance \\
Week 04 & Historical Toponomastics as an Etymological Science \\
Week 05 & Quiz 1 and Review \\
Week 06 & Diachronic Toponymy and Language Documentation \\
Week 07 & Place Names' Etymological Reconstructions \\
Week 08 & Language Contact in Prehistoric Context \\
Week 09 & Historical Toponomastics and Pre-Languages \\
Week 10 & Toponymy in Contact Areas \\
Week 11 & Toponymic and Lexical Stems \\
Week 12 & Quiz 2 and Review \\
Week 13 & Odonymy in Multicultural and Multilingual Areas: The Singapore Odonymy Case Study \\
\hline
\end{tabular}

Throughout the 13 weeks, there is also a list of complementary topics, which provides the students with additional insights into Toponymy. These topics are shown in Table 2 and are also covered in the lessons as a supplement to the topics listed in Table 1.

Table 2. Complementary topics covered in HG2093.

\begin{tabular}{|c|c|}
\hline Week Number & Complementary Topic(s) \\
\hline Week 01 & Toponymic Reconstruction of a root + suffix place name (Saliceto) \\
\hline Week 02 & Critical Toponymy and the Toponymic Reconstruction of an Etymologically Obscure Place Name (Vinchio) \\
\hline Week 03 & Toponymic Reconstruction of an Apparently Transparent Place Name (Franciacorta) \\
\hline Week 04 & Toponymic Reconstruction of a Prehistoric Toponymic System (the Alba model) \\
\hline Week 05 & Toponymy in Multicultural Contexts and the Notion of 'Commodification of Place Names' \\
\hline Week 06 & A Papuan Toponymic System from South-East Indonesia (Afena) \\
\hline Week 07 & $\begin{array}{c}\text { Traditional Etymological Methodologies vs Experimental Etymological Methodologies in Toponymic } \\
\text { Reconstruction }\end{array}$ \\
\hline Week 08 & Toponymic Reconstruction between Proto-Languages and Pre-Languages \\
\hline Week 09 & Toponymic Reconstruction of the *borm- Toponymic System \\
\hline Week 10 & A Theory on Toponymic Convergence between Celtic and Etruscan \\
\hline Week 11 & Toponymic Reconstruction of the *kar- / ${ }^{*} \mathrm{kal}$ - Toponymic System and its links to the Landscape \\
\hline Week 12 & Human Geography, Cultural Geography, Landscape and Toponymy \\
\hline Week 13 & Synchronic Toponymy \\
\hline
\end{tabular}


To assess students' understanding on these areas throughout the Semester, the course has a $100 \%$ coursework-based approach. Assessment components typically involve two in-class quizzes to test conceptual understanding on content covered in classes $(20 \%$ and $35 \%)$, a free-topic essay on Toponymy of 2000 words (30\%), a group presentation on any aspect on Toponymy and Toponomastics (5\%) and active class participation $(10 \%)$. This assessment format rewards engaged and consistent participation throughout the course, to which students often demonstrate. Past topics researched about and presented be it in the essay or group presentation include disputed place names in different parts of the world, commemorate street naming, selected case studies on how places in Singapore got their names, political and cultural influences on toponyms, among many others.

The analysis relies on the repository of slides used for the module, which is available on NTULearn, a virtual learning environment and learning management system developed together with Blackboard Inc. While there are weekly readings, these chapters and journal articles are optional and, thus, the slides form the basis of instruction for this module. The slides have been downloaded and comprehensively analyzed, noting the contents, examples and analyses of the various topics. Thereafter, the authors provide snapshots illustrating major themes of the course relating to Landscape Education. These two themes (diachronic-synchronic and urban-rural) conform to the temporal and spatial dimensions of the landscape which have been listed as teaching principles in Landscape Education to introduce the subject of landscapes and to present topics related to the landscape $[20,21]$. These themes appear on an axis and at first glance, might appear at odds with each other. However, they ultimately serve as a model on how Landscape Education incorporates a great diversity of perspectives, be it temporal or spatial ones or even the disciplines used to approach the landscape. The module provides a useful case study of different mental models and disciplines contributing to students' understanding of the landscape around them.

\section{Different Time Perspectives: Diachronic and Synchronic}

\subsection{Diachronic}

The landscape can be approached from a diachronic perspective, aided by study of Etymology and Historical Linguistics in studying how the meaning and morphology of the place and place name has changed over time.

An example is seen in Week 4 in the etymological reconstruction of the Italian place name Borgomale. Students are "taken" to Borgomale, a municipality located in the Cuneo province, Piedmont, North-Western Italy. The place name Borgomale can be broken down, in Italian, into borgo 'village' or 'hamlet' and male 'bad' or 'evil' and thus is known as the 'bad village' or 'village of evil.' Inhabitants of the village say that because previous villagers were evil, the village was punished. It almost disappeared during the Black Death and has remained very small ever since. However, the lecturer shows the class documents such as the church records (the church normally keeps these files of births and deaths in the region) and concludes that the number of inhabitants has historically been stable and did not vary, even during the Black Death. The lecturer also notes that the area previously was dotted with apple trees, evidenced by ancient drawings and documents (see Figure 1). Thus, there needs to be a transparent reason for the place name, one which accounts for these facts as well as the language change of the name (both in terms of their morphology and meaning). 


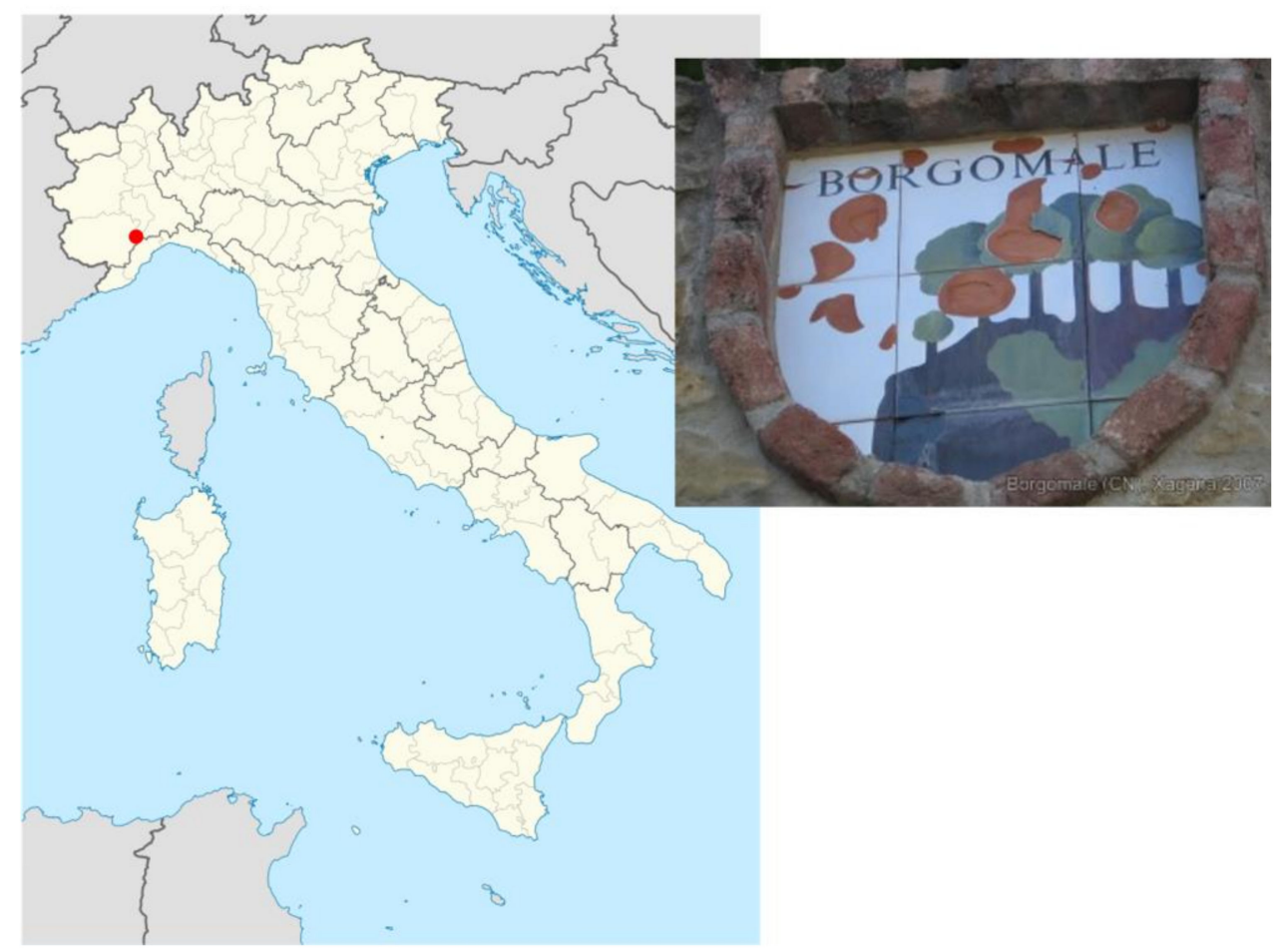

Figure 1. A slide from Week 4 indicating the location of Borgomale in Italy and the emblem or coat of arms of the municipality's logo. The red drawings are evidence of apple trees that formerly grew in the region.

Linguistic data is provided in analyzing the Latin and Italian forms of both borgo and male. It is explained that Italian, a neo-Latin Romance language, descended from the vulgar late variant of Latin, an Indo-European language. The Italian borgo comes from the Latin burgus 'village' or 'hamlet,' while the Italian male comes from the Latin malum (genitive mali) 'evil.' Further linguistic analysis, however, shows that the Italian male can be traced back to two forms of the Latin word malum, differentiated only by the length of the vowel /a/. One is mălum (pronounced with a short vowel $\breve{a}$ ), which means 'evil' and became the Italian word male 'evil' and malo 'bad.' The other is mālum (pronounced with a long vowel $\bar{a})$, which means 'apple' or 'apple tree' and became the Italian word mela ('apple') and melo ('apple tree'). According to locals' postulation, Borgomale was argued to have come from the Latin expression Burgus Măli 'village of evil'.

However, looking at historical documents and the emblem of the municipality, it is possible to conclude that apple trees existed in the area, possibly during the Middle Ages and the Modern Age. It is, hence, more plausible, that Borgomale came from Burgus Māli, 'village of the apple(s)' or 'village of the apple tree(s).' The reconstructed form in modern Italian should thus be *Borgomela, 'village of the apple' or *Borgomelo 'village of the apple tree.' Yet, the reconstructed form is Borgomale 'bad village' or 'village of evil.' The reason for this is argued to be one of a semantic misunderstanding, which generates toponymic paretymology; because of the evolution of languages and the transition between one language to another (in this case, from Latin to Italian), speakers try to explain an otherwise obscure place name through their linguistic (in)competence [52]. In Latin, a distinguishing factor in the meaning of words, such as malum is the pronunciation. However, this linguistic aspect of Latin was lost when Latin started its vernacular phase and eventually evolved into neo-Latin Romance languages like Italian, which is spoken by the villagers today. Given that these villagers do not speak Latin, they are unable to differentiate or perceive this pronunciation and are, thus, unaware of the actual roots of the toponym. As such, they invented the story of the Black Death to associate "bad" with the village and to explain the reasons of the name (by producing a toponymic paretymology), which ignores the landscape features of apple trees that existed in this commune. Therefore, although the 
Latin name of Borgomale was Burgus Māli 'village of the apple tree' and the correct Italian reconstructed form should be *Borgomelo or *Borgo Melo 'the village of the apple tree,' speakers misunderstanding of Latin, the language where Borgomale's original roots can be traced to, meant that the current attested but incorrect form, Borgomale became widespread, to which speakers trace to Burgus Măli 'bad village' or 'village of evil.'

Several themes emerge from this example. The first would be the value of the discipline of Etymology in studying Toponymy and the landscape. The lecturer concludes the case study by noting that studying the etymology of a place name requires "a physical evaluation of the hydro-geo-morphology of the territories and human settlements under investigation" and this process is "aimed at correlating the possible links of a place name with the landscape and to ascertain whether any dramatic changes have occurred to the landscape, confirming or disproving etymological hypotheses" [53]. In studying the etymology of Borgomale, the lecturer drew on the geo-morphology of the commune (for example, what trees/crops were grown there) as well as features of the human settlements by studying historical records (for example, church documents which recorded births and deaths in the area) with the objective of correlating the relationship of the toponym (and its meaning) to the environmental and anthropic facilities of the landscape in Borgomale. It is also a useful case in point on the inter-relationship between Languages, HistoricalStructural Linguistics, History, Landscapes (both physical and human) and Toponymy. Furthermore, students can also see how the perceived character of an area is influenced by the interaction of human forces, as outlined by the ELC [2]. Italian speakers in Borgomale might not understand the linguistic elements behind the Latin place name and thus, came up with the story of how people in the village died during the Black Death-an example not just in toponymic paretymology but also a case in point on how speakers use language and stories to perceive and explain their relationship to the landscape and environment. While the case study of Borgomale might not be rooted in Asia or a local context, learning about the "true" meaning and origins of this place name meets the course's objective of learning how to reconstruct the etymological origins of place names from across the globe. Furthermore, as students have demonstrated in their essays and group presentations, they were able to use such etymological tools of analyses in reconstructing the meaning and origins of Singaporean toponyms by analyzing the physical and human landscapes of the place, as well of historical documents connected with the area, whilst taking into account the languages commonly spoken in the country during the period the place was named-all of which can be observed in the lesson on Borgomale.

\subsection{Synchronic}

The module also provides students important information relating to current research on Toponymy of a place at a specific, given time and how it relates to the landscape. In the second week of the course, students are asked: how are toponyms classified, especially in relation to the landscape? In this lesson, they are introduced to George Stewart's seminal work on the classification of place names. The lecturer shows the class Stewart's ten categories for classifying places which was delineated in his 1975 book, Names on the Globe [54], although the idea of toponymic classification had already been put forth by Stewart in his earlier works $[55,56]$. Stewart's ten categories for classifying place names remains widely influential and forms the basis of present research on toponymic classifications as well [57-59]. Through this, students become aware that places are named in reference to the landscape, a process which is indicated in the classification system. Once again, in certain naming groups, students witness the connections between humans and the environment they live in as people name their landscapes according to criteria that not only "makes sense" to them but also reflects the community's identity. Examples of Stewart's classification categories (see Figure 2) include descriptive names (place names that describe the quality or location of the place; these toponyms essentially name traits about the landscape), incident names (place names from an event associated with a person and the natural landscape becomes connected with humans because of certain historical 
events that occurred there) and shift names (names that have been transferred from one landscape type to another).

\section{Toponymic Classification}

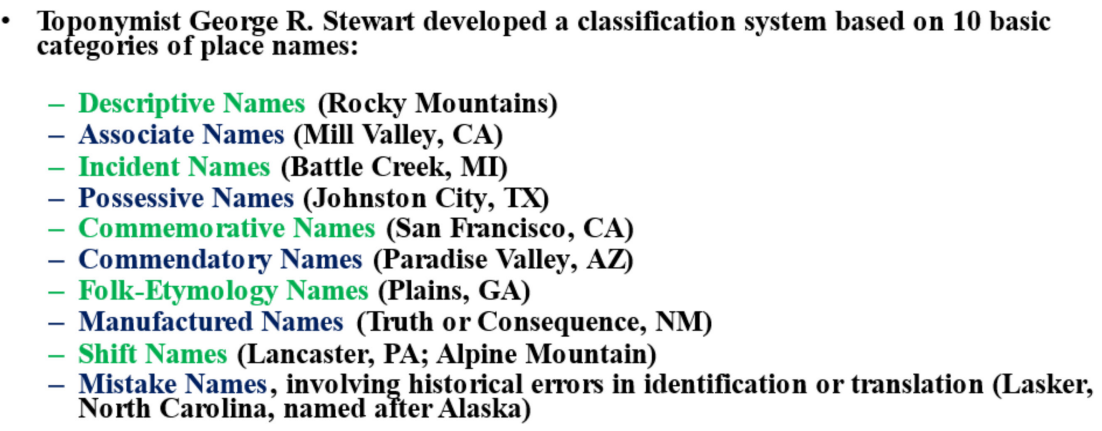

Figure 2. A slide from Week 2 showing Stewart's classification categories and some examples of these categories found in American toponyms.

The module also touches on the politics of renaming, an area that has received significant attention in the last decade and continues to influence methodologies in present studies on Toponymy and Human Geography [60-65]. The politics of renaming is influenced by and related to the Critical Toponymy Theory, which focuses on the "political and cultural choices involved in attributing —or not attributing-a place name" [66] (p. 143). The example provided in the lecture is that of the former Union of Soviet Socialist Republics (USSR), where, at least 27 cities were named after Vladimir Lenin (the most notable was Leningrad) and at least 12 cities were named after his successor, Joseph Stalin (the most prominent was Stalingrad). However, many of these cities were renamed after the fall of the Soviet Union and Communism. Leningrad is now Saint Petersburg while Stalingrad has been re-termed Volgograd. The enduring understand here is: "Toponymy can reveal the political parties and politicians in charge at the time a place got its name or those who had influenced the naming process further in the past" [67]. In this sense, the landscape, through the naming process, is subjected to political power at play-both by regimes that have long been removed (as seen in the USSR example) or even recent political changes [68]. Especially in built-up environments, toponyms and the toponymic naming process are used by governments and their agencies to "create administrative boundaries, demonstrate political authority, define spatial problems, shape and legitimize political subjects and articulate territorial policy agendas" [69] (p. 1601) and builds on the understanding that humans shape their environment through the realm of political action and power structures. A further example provided in the lesson demonstrating how politics influences toponyms and landscape is that of toponyms and cartography. Contested places often have more than one name at the same time and, depending on where the map is produced, the exact place can have different names. For instance, the British believe they own Falkland Islands (and British maps reflect this), which the Argentinians, who contest this, call the Malvinas (which is also shown in Argentinian maps). The giving of different names, the lecturer argues, is an attempt to demonstrate the political authority of both sides (since one of the methods in which political power is exercised is via naming places) and a way to legitimize control over the islands which is linked to the sovereignty of both countries [67].

An interesting way of conceptualizing the landscape is found in a lesson on Sequent Occupance in Week 3. The notion originates from Derwent Whittlesey, a prominent geographer who developed it in 1929 and is "a concept used to describe the current cultural landscape of a region, as a combination of all the cultures which have 'sequentially' occupied the region from the past to the present" [70]. This means that an area might have been occupied by one civilization, followed by another and so on. However, the 
cultural imprint of each civilization is never completely lost; each civilization adds on to the cultural markings of the previous civilization and collectively, these cultural inscriptions can be seen till today. The example in the lesson is that of Tanzania, which was ruled, at different times, by the Portuguese, the Arabs, the Germans and the British. The country also has a sizeable population of Indian origin due to migration from India around the 19th century. Consequently, the largest city, Dar es Salaam, through its landscape architecture and toponyms, reveal influences from these cultures and local Tanzanian culture as well. This concept is an interesting way to think about the urban and cultural landscape, which can be likened to building a brick house. Each civilization places one layer of the brick house. Due to events like colonization and migration, more civilizations might inhabit the area and build on the existing cultural layer. The result would be a structure of many (cultural) layers laid upon each other, where each layer can be attributed to a particular culture and civilization and overlaps with the one before it. It is also worth noting that the concept of Sequent Occupance has gained prominence in the study of Singapore's toponyms in recent years. Cavallaro, Perono Cacciafoco and Tan's 2019 paper applied the Sequent Occupance theory to ten local toponyms and find that "the influences of all the cultures which have "sequentially" occupied Singapore from the past to the present can be seen in the history of its place names" with a "willingness by the colonial masters at first, and the new independent government later, to accommodate this diversity in the toponyms and odonyms of this now very international city" [71].

\section{Different Spatial Features: Rural and Urban}

\subsection{Rural}

The course also touches on the landscape in rural contexts and how it is nested within place names. Although this is approached from a Historical Toponomastics angle, students nonetheless gain greater insights about how people from rural societies interact with their physical landscape and organize their knowledge (as evident in the place naming process). This is seen in Week 6 in the Abui case study, an example based on the lecturer's fieldwork on the Abui language, spoken in Alor Island, located in South-East Indonesia. Abui remains an undocumented language and inhabitants rely on oral transmission of knowledge.

Students are shown a series of toponyms_Lamang Tāha, Lamang Uwo and Lalamang. These toponyms are part of a toponymic system or a group of place names related to each other. The lecturer shows that according to fieldwork done in the case of Lamang Täha and Lamang Uwo, the meaning of lamang is unclear, although tāha means 'above' while uwo means 'below.' Locals have also indicated that Lalamang can be parsed into 'village of the good wood for houses.' The prefix la- is so common that it is part of the toponymic system and present in all three toponyms. Yet, nothing is known about it and hence, warrants an investigation on its meaning.

There are two possible ways for breaking up Lalamang:

$$
\begin{aligned}
& \text { la-lamang } \\
& \text { lala-mang }
\end{aligned}
$$

Further investigation and fieldwork studies point to the second one being more plausible because the meaning of -mang is 'place' or 'village' and is contracted from melang, an Abui term for 'place' or 'village.' Given that Lalamang means 'the village of the good wood for houses' and -mang means 'place' or 'village,' it is possible to conclude that the prefix la- is 'good wood for houses' or 'good wood.' The form lala-, in Lalamang, thus derives from the reduplication (or repeat) of the original root la-. This feature of reduplication is common in Abui toponyms and Abui grammar as well [52]. The linguistic analysis and fieldwork process enabled the recovery of the original meaning of unclear place names. The original meanings of Lamang Tāha, Lamang Uwo and Lalamang is linked to a renewable natural source (evident in la- 'good wood for houses') combined with the toponymic indication of village (expressed by -mang 'place' or 'village'). These findings reflect the 
broader trend of using plants and natural sources to name villages in Alor Island, as indicated by previous research [72,73].

The Abui example shows the linkage between the speakers and their environment. Abui speakers live in an agrarian society and thus rely greatly on crops and plants in their lifestyles. As such, place names also reflect this dependence on these natural sources and are named according to frequently cultivated crops or qualities associated with these crops (for instance, village of the good wood). Beyond encoding the relationships between speakers and the physical landscape, this serves as an opportunity for students to read landscapes in rural contexts and in the process, encourage a "sensitization to relations between cadre de vie and landscape" [5]. Also relevant are the links between language and toponyms; an understanding of the Abui language achieved through fieldwork and language documentation ultimately aided the deciphering of the "unknown" place names and shows that toponyms are not just valuable landscape resources but linguistic tools as well-findings which are supported in other scholarly works which prove how toponyms are strongly rooted in physical characteristics of the land (such as hills and valleys, trees and forests) and that these place names point to people having a vast topographical vocabulary to name their landscape [36].

\subsection{Urban}

The final lecture of the course, entitled Odonymy in Multicultural and Multilingual Areas: The Singapore Odonymy Case Study, winds up the course through choosing a case study in a context most students are familiar with Singapore-an urban city-state. The lecture content comes from a study [46] aimed at examining naming practices among Singapore's odonyms (street names) derived from three languages-English, Malay and Chinese. Fifty names from each source language were selected via random sampling and analyzed for their naming practices as well as the reasons for the trends observed in naming practices (see Figure 3 for the results of this study).

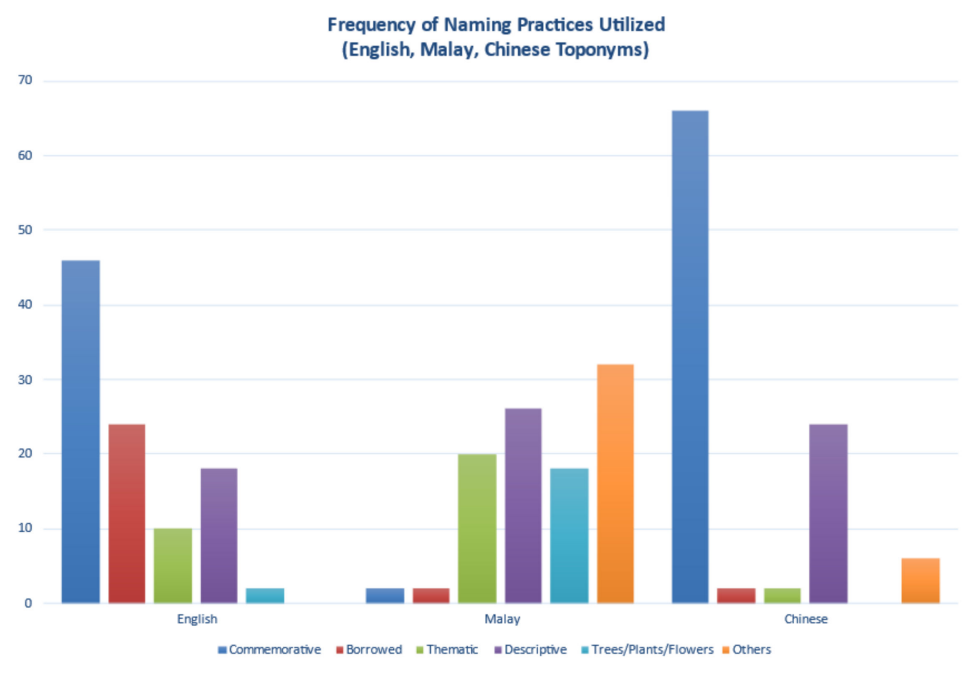

Figure 3. Results of this study was tabulated and presented in a graphic format. In this slide, students can see the number of streets (i.e., the frequency) in each language studied (i.e., English, Malay and Chinese), which are named according to the particular naming practice.

Connections to previous concepts covered in the course can be drawn. The Sequent Occupance theory, where cultures of previous civilizations occupying the locality shape the cultural landscape, is evident in the Singapore odonymy case study. Singapore was a former British colony. Many English street names, which were given during colonization, thus commemorate European individuals and their family members (for example, Jervois Road and Crawford Street were named after British governors and councilors of Singapore). 
English names were also borrowed from similar places in Britain (for example, Berwick Drive and Moreton Close) or named after their colonies (for example, Canada Road and Kenya Crescent). As previously argued, place names are intertwined with governmentality and thus, these commemorative and borrowed names were also a tool by the British to demonstrate their political power and authority in Singapore.

Moreover, similar trends are noted in Chinese language odonyms. The lecturer pointed out that many Chinese-derived odonyms commemorate Chinese people in Singapore (for example, Boon Lay Avenue is named after the businessman Chew Boon Lay), their wives (for example, Pek Hay Road is named after Wi Pek Hay, the wife of the famous pineapple planter Lim Nee Soon) and in some cases, named after an entire family (for example, Yio Chu Kang Road is named after the Yio family). This could be due to values held in a collectivist culture, where honor is shared by the family and thus, the act of commemoration is extended beyond individuals to include their family members. There are also auspicious names recorded in Chinese odonyms (for example, Tai Keng Avenue, meaning 'big celebration' and Sengkang Street meaning 'prosperous harbor') -a trend linked to the emphasis on positive connotations in the semantics of words in the Chinese culture.

While it is evident that the cultures of people who inhabited and continue to inhabit Singapore are witnessed in toponyms, place names are also strongly associated with landscapes, the concept of space and the spatial-planning issues. In Singapore, this is evident in the presence of descriptive toponyms in the three languages studied. Descriptive names, according to the study, are named after the primary economic and agricultural activities that had flourished in their corresponding areas or landscape and/or anthropic facilities that once existed in the locality [46]. Examples include Nutmeg Road, Lentor Avenue (derived from the Malay word, lentur 'bend' due to the curved shape of the road) and Chai Chee Road (due to the presence of a vegetable market that once stood behind the road). These findings reflect how place names are primarily coined to identify the location, a process which happens with knowledge of the physical landscape and human activities occurring there. In this lesson, studying the names of the landscape becomes a teaching resource. While students might know of these street names, this particular lesson strategically positions visible signs of their surroundings (see Figure 4) as the object of study, analyzing these street names according to sociolinguistics, historical, political and other spatial-planning factors. In the process, they develop a better appreciation of socio-cultural and linguistic issues in landscape and street planning in the urban city-state they live in. At the same time, there is a synthesis of critical concepts impacting global research like Sequent Occupance and Critical Toponymy Theory, which students, in this lesson, relate to their local context.

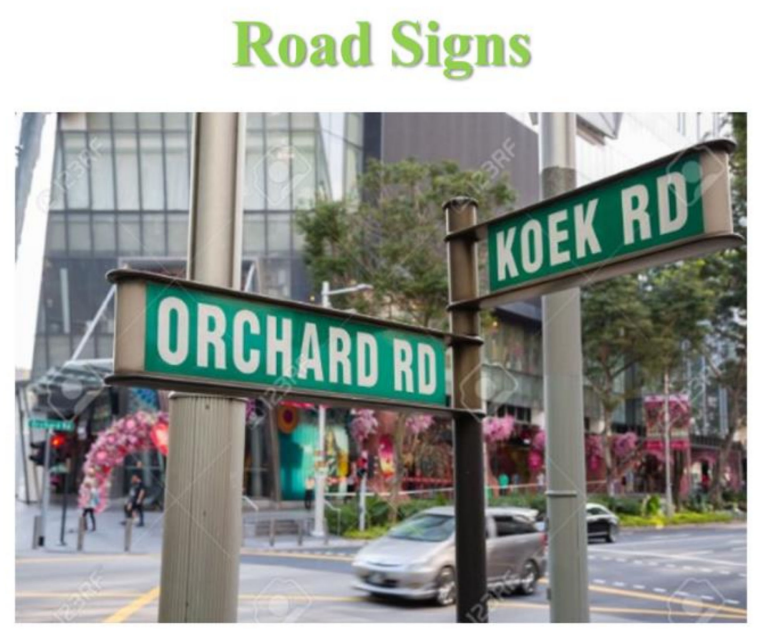

Figure 4. In this lesson, Singaporean street signs, which are seen on this slide, are made the object of study, while also applying previous concepts in a local case study. 


\section{The Drawing from Different Disciplines and Final Conclusions}

The module introduction in Week 1 begins with a quote with reference to the diachronic study of Toponymy. "It is widely recognized that toponyms provide valuable insight into the Historical Linguistics, Historical Geography, Topography and Landscape Archaeology of a specific region or area" [74]. Moreover, place names, according to the introductory lesson, can also be studied at a specific moment in time, thereby providing a synchronic lens to Toponymy. Related to the synchronic approach are issues of language policy and planning, cultural values, social factors influencing language use, sociolinguistics, among others. These disciplines are connected to and approach the study of natural and man-made landscapes through multiple angles. In this sense, one can see how Landscape Education can be weaved into the curriculum at university-level relying on a holistic, multidisciplinary approach.

Throughout the course of thirteen weeks, students begin to see the intersections of different disciplines coming together. While a study of place names, which is the focus and name of this module, provides crucial information on how the landscape has changed over time, as well as how people interact (which is oftentimes encoded in and through language and narrative strategies) with their environment, as seen in the case study of Borgomale. Students simultaneously develop an awareness of different frameworks in approaching the landscape. They achieved this through studying the origins and meanings of place names over time, as in the Borgomale and Abui case studies (connected with Historical Linguistics and Etymology), through looking at old maps in the Borgomale lesson and how the locality was visually represented before (associated with Historical Geography, Historical Topography and Historical Cartography), through documenting and sharing fieldwork findings in rural contexts such as Alor Island (bringing together Field Linguistics, Language Documentation and Anthropological Linguistics methods), through encountering ways in which humans organize and make sense of place names and by extension, their physical landscape as well as frameworks that will continue to influence future global research directions such as Sequent Occupance and Critical Toponymy Theory (linked to Human Geography, Politics and Governmentality Studies and Urban Studies) and finally, putting all of these together in a local context in the Singapore odonymy lesson. The final lesson concluding this course provides a synthesis of how regional and global case studies and concepts from places that students might not be familiar with can be applied into the Singaporean landscape.

Through approaching the landscape from a myriad of disciplines, the landscape, in through this module, becomes the building axis of knowledge from both local and global perspectives, incorporating different dominant features (rural-urban) and with analyses spanning across different time periods (diachronic-synchronic)—reflecting an interdisciplinary approach whereby participating disciplines, at the academic level, cooperate and contribute their skills to enhance landscape teaching. More importantly, it is also an example of how the module is structured and taught in line with existing pedagogical frameworks in Landscape Education [20,21]. In the final analysis, this module on Toponymy is a useful exercise in how Landscape Education may be incorporated to a diversity of pre-existent curricular paths through education in several disciplines, as highlighted by the ELC [4], as well as how studying the landscape presents "an opportunity to develop an experiential, ethical and emotional interdisciplinary model of integrated education" [75] (p. 255).

Author Contributions: Conceptualization, S.T.G.L.; methodology, S.T.G.L., F.P.C.; documentary research, S.T.G.L., validation, F.P.C.; formal analysis, S.T.G.L., F.P.C.; investigation, S.T.G.L., F.P.C.; resources, F.P.C.; writing—original draft preparation, S.T.G.L.; writing—review and editing, F.P.C.; supervision, F.P.C. All authors have read and agreed to the published version of the manuscript.

Funding: This research received no external funding.

Conflicts of Interest: The authors declare no conflict of interest. 


\section{References}

1. Peart, R. A Place to Stand: The Protection of New Zealand's Natural and Cultural Landscapes; Environmental Defense Society: Auckland, New Zealand, 2004.

2. Council of Europe. European Landscape Convention (European Treaty Series-No. 176). Available online: https://rm.coe.int/16 80080621 (accessed on 18 January 2021).

3. Dejeant-Pons, M. The European Landscape Convention. Landsc. Res. 2006, 31, 363-384. [CrossRef]

4. Gómez-Zotano, J.; Riesco-Chueca, P. Landscape learning and teaching: Innovations in the context of the European Landscape Convention. In Proceedings of the INTED2010 (International Technology, Education and Development 2010) Conference, Valencia, Spain, 8-10 March 2010; pp. 4703-4714.

5. Committee of Ministers. Recommendation CM/Rec(2008)3 of the Committee of Ministers to Member States on the Guidelines for the Implementation of the European Landscape Convention. Available online: https:/ /rm.coe.int/16802f80c9 (accessed on 18 January 2021).

6. Orlandini, O.Z. Lo sguardo sul paesaggio da una prospettiva pedagógico-ambientale. In Il Paesaggio Vicino a Noi. Educazione, Consapevolezza, Responsabilità, Proceedings of the Museo Civico di Storia Naturale e Archeologia Conference, Montebelluna, Italy, 24 March 2005; Castiglioni, B., Celi, M., Gamberoni, E., Eds.; Museo di Storia Naturale e Archeologia: Montebelluna, Italy, 2005.

7. Siama, I.; Terkenli, T.S.; Klonari, A. Building a landscape educational program for the needs of Greek preschool and primary-school children: A methodological approach. Eur. J. Geogr. 2018, 9, 80-90.

8. Terkenli, T.S.; Daras, T.; Efpraxia-Aithra, M. Landscape notions among Greek engineering students: Exploring landscape perceptions, knowledge and participation. Land 2019, 8, 83. [CrossRef]

9. Castiglioni, B.; Cisani, M. The complexity of landscape ideas and the issue of landscape democracy in school and non-formal education: Exploring pedagogical practices in Italy. Landsc. Res. 2020, 1-13. [CrossRef]

10. Greinert, A.; Mrówczynska, M. The impact of the process of academic education on differences in landscape perception between the students of environmental engineering and civil engineering. Land 2020, 9, 188. [CrossRef]

11. Gómez-Gonçalves, A.; Corrochano, D.; Fuertes-Prieto, M.A.; Ballegeer, A. How long has it taken for the physical landscape to form? Conceptions of Spanish pre-service teachers. Educ. Sci. 2020, 10, 373. [CrossRef]

12. Jørgensen, K.; Karadeniz, N.; Mertens, E.; Stiles, R. (Eds.) The Routledge Handbook of Teaching Landscape; Routledge: Oxford, UK; New York, NY, USA, 2019.

13. Siama, I.; Terkenli, T.S.; Klonari, A. Implementing a landscape educational project among Greek pupils: Valuable lessons and hard realizations. Intl. J. Educ. 2020, 8, 39-53. [CrossRef]

14. Riesco-Chueca, P.; Gómez-Zotano, J. Landscape fieldwork: Scientific, educational and awareness-raising requirements in the context of the European Landscape Convention. Landsc. Res. 2013, 38, 695-706. [CrossRef]

15. Ruggeri, D.; Fetzer, E. The digital classroom as landscape democracy arena. Toward a socially transformative pedagogy in design and planning. In Lessons from the Past, Visions for the Future: Celebrating One Hundred Years of Landscape Architecture Education in Europe, Proceedings of the ECLAS and UNISCAPE Annual Conference 2019, Ås, Norway, 16-17 September 2019; Gao, L., Egoz, S., Eds.; Norwegian University of Life Sciences: Ås, Norway, 2019; pp. 31-32.

16. Creţan, R.; Light, D.; Richards, S.; Dunca, A.M. Encountering the victims of Romanian communism: Young people and empathy in a memorial museum. Eurasian Geogr. Econs. 2018, 59, 632-656. [CrossRef]

17. Creţan, R. Mapping protests against dog culling in post-communist Romania. Area 2015, 47, 155-165. [CrossRef]

18. Newsome, D.; Dowling, R.; Leung, Y.F. The nature and management of geotourism: A case study of two established iconic geotourism destinations. Tour. Manag. Perspect. 2012, 2-3, 19-27. [CrossRef]

19. Mocior, E.; Kruse, M. Educational values and services of ecosystems and landscapes-An overview. Ecol. Indic. 2016, 60, 137-151. [CrossRef]

20. Antrop, M.; Van Eetvelde, V. From teaching geography to landscape education for all. In The Routledge Handbook of Teaching Landscape; Jørgensen, K., Karadeniz, N., Mertens, E., Stiles, R., Eds.; Routledge: Oxford, UK; New York, NY, USA, 2019; pp. 31-44.

21. Vos, W.; Meekes, H. Trends in European cultural landscape development: Perspectives for a sustainable future. Landsc. Urban Plan. 1999, 46, 3-14. [CrossRef]

22. Darby, H.C. Place names and geography. The Geogr. J. 1957, 123, 387-392. [CrossRef]

23. David, B.; Thomas, J. (Eds.) Handbook of Landscape Archaeology; Routledge: Abingdon, UK, 2008.

24. Layton, R.; Ucko, P. (Eds.) The Archaeology and Anthropology of Landscape: Shaping Your Landscape; Routledge: London, UK, 1999.

25. Jones, R. Place-names in landscape archaeology. In Detecting and Understanding Historical Landscapes; Arnau, A.C., Reynolds, A., Eds.; SAP Societa Archeologica: Mantua, Italy, 2015; pp. 209-224.

26. Anschuetz, K.; Wilshusen, R.; Scheick, C. An archaeology of landscapes: Perspectives and directions. J. Arch. Res. 2001, 9, 157-211. [CrossRef]

27. Creţan, R.; Matthews, P.W. Popular responses to city-text changes: Street naming and the politics of practicality in a post-socialist martyr city. Area 2016, 48, 92-102. [CrossRef]

28. Vesalon, L.; Creţan, R. 'Little Vienna' or 'European avant-garde city'? Branding narratives in a Romanian City. J. Urban Reg. Anal. 2019, 11, 17-34. [CrossRef]

29. Brasher, J.P.; Alderman, D.H.; Subanthore, A. Was Tulsa's Brady Street really renamed? Racial (in)justice, memory-work and the neoliberal politics of practicality. Soc. Cult. Geogr. 2020, 21, 1223-1244. [CrossRef] 
30. Creţan, R. Who owns the name? Fandom, social inequalities and the contested renaming of a football club in Timisoara, Romania. Urban Geogr. 2019, 40, 805-825. [CrossRef]

31. Post, C.W.; Alderman, D.H. 'Wiping New Berlin off the map': Political economy and the de-Germanisation of the toponymic landscape in First World War USA. Area 2014, 46, 83-91. [CrossRef]

32. Situ, S. Historical geographical study of place names in Guangdong. J. Chin. Hist. Geogr. 1992, 1, 21-55.

33. Deepadung, S. Toponyms in the western region of Thailand. MANUSYA 2003, 6, 31-65. [CrossRef]

34. Zhu, Z.; Zhang, H.; Zhao, J.; Guo, X.; Zhang, Z.; Ding, Y.; Xiong, T. Using toponyms to analyze the endangered Manchu language in Northeast China. Sustainability 2018, 10, 563. [CrossRef]

35. Zhao, F.; Fu, Y.; Luan, G.; Zhang, S.; Cai, J.; Ding, J.; Qian, J.; Xie, Z. Spatial-temporal characteristic analysis of ethnic toponyms based on spatial information entropy at the rural level in Northeast China. Entropy 2020, 22, 393. [CrossRef] [PubMed]

36. Gelling, M.; Cole, A. The Landscape of Place-Names; Shaun Tyas: Lincolnshire, UK, 2000.

37. Hirsch, E.; O'Hanlon, M. (Eds.) The Anthropology of Landscape: Perspectives on Place and Space; Oxford University Press: Oxford, UK, 1995.

38. Everett-Heath, J. Place Names of the World: Europe: Historical Context, Meanings and Changes; Macmillan Press: London, UK, 2000.

39. Klugah, M.A. Recounting history through linguistics: A toponymic analysis of Asogli migration narratives. Afr. J Hist. Cult. 2013, 5, 151-159.

40. Perono Cacciafoco, F.; Cavallaro, F. The legend of Lamòling: Unwritten memories and diachronic toponymy through the lens of an Abui myth. Lingua 2017, 193, 51-61. [CrossRef]

41. Poenaru-Girigan, O. The relationship between toponymy and linguistics. Anadiss 2013, 1, 154-166.

42. Balmer, J.M.T. Corporate heritage, corporate heritage marketing, and total corporate heritage communications. What are they? What of them? Corp. Comms. 2013, 18, 290-326. [CrossRef]

43. Hakala, U.; Sjöblom, P.; Kantola, S. Toponyms as carriers of heritage: Implications for place branding. J. Prod. Br. Manag. 2015, 24, 263-275. [CrossRef]

44. Mailhammer, R. Place names as clues to lost languages? A comparison between Europe and Australia. In Language, Land E Song: Studies in Honour of Luise Hercus; Austin, P.K., Koch, H., Simpson, J., Eds.; EL Publishing: London, UK, 2016 ; pp. 318-329.

45. Perono Cacciafoco, F.; Nanetti, A. Linguistic contact in prehistoric Italy: At the origins of the placename Imola. Names 2015, 63, 158-170. [CrossRef]

46. Perono Cacciafoco, F.; Tuang, S.Q. Voices from the streets: Trends in naming practices of Singapore odonymy. Rev. Hist. Geogr. Toponomast. 2018, XIII, 9-30.

47. Tent, J. Approaches to research in toponymy. Names 2015, 63, 65-74. [CrossRef]

48. Nash, J. The how of toponymy: A comment on Tent's "Approaches to research in toponymy". Names 2015, 63, 233-236. [CrossRef]

49. Corporate Information: NTU Rankings and Ratings. Available online: https:/ /www.ntu.edu.sg/AboutNTU/CorporateInfo/ Pages/universityrankings.aspx (accessed on 19 January 2021).

50. Undergraduate Course Descriptions. Available online: http://www.soh.ntu.edu.sg/Programmes/linguistics/Undergraduate\% 20Programme/Pages/Course-Descriptions.aspx (accessed on 19 January 2021).

51. Perono Cacciafoco, F. Course Outline for HG2093 Discovering Unwritten Stories: A General Introduction to Toponymy and Toponomastics. Available online: https://ntulearn.ntu.edu.sg/ (accessed on 19 January 2021).

52. Perono Cacciafoco, F.; Cavallaro, F.; Kratochvíl, F. Diachronic toponomastics and language reconstruction in South-East Asia according to an experimental convergent methodology: Abui as a case-study. Rev. Hist. Geogr. Toponomast. 2015, X, $29-47$.

53. Perono Cacciafoco, F. HG2093 Week 4: Historical Toponomastics as an Etymological Science. Available online: https://ntulearn. ntu.edu.sg/ (accessed on 19 January 2021).

54. Stewart, G.R. Names on the Globe; Oxford University Press: Oxford, UK, 1975; pp. 85-162.

55. Stewart, G.R. Names on the Land: A Historical Account of Place-Naming in the United States; Random House: New York, NY, USA, 1945; For an updated edition, please see Stewart, G.R. Names on the Land: A Historical Account of Place-Naming in the United States; NYRB Classics: New York, NY, USA, 2008.

56. Stewart, G.R. A classification of place names. Names 1954, 2, 1-13. [CrossRef]

57. Tent, J.; Blair, D. Motivations for Naming: A Toponymic Typology; Australian National Placenames Survey: South Turramurra, NSW, Australia, 2009.

58. Tent, J.; Blair, D. Motivations for naming: The development of a toponymic typology for Australian placenames. Names 2011, 59, 67-89.

59. Urazmetova, A.V.; Shamsutdinova, J.K. Principles of place names classifications. XLinguae 2017, 10, 26-33. [CrossRef]

60. Berg, L.; Vuolteenaho, J. (Eds.) Critical Toponymies: The Contested Politics of Place Naming; Ashgate: Aldershot, UK; Burlington, VT, USA, 2009.

61. Rose-Redwood, R.; Alderman, D.; Azaryahu, M. Geographies of toponymic inscription: New directions in critical place-name studies. Prog. Human Geogr. 2010, 34, 453-470. [CrossRef]

62. Rose-Redwood, R.; Alderman, D. Critical interventions in political toponymy. ACME Int. E J. Crit. Geogr. 2011, 10, 1-6.

63. Light, D.; Young, C. Toponymy as commodity: Exploring the economic dimensions of urban place names. Intl. J. Urban. Reg. Res. 2015, 39, 435-450. [CrossRef] 
64. Light, D.; Young, C. The politics of toponymic continuity: The limits of change and the ongoing lives of street names. In The Political Life of Urban Streetscapes: Naming, Politics and Place; Rose-Redwood, R., Alderman, D., Azaryahu, M., Eds.; Routledge: Oxford, UK; New York, NY, USA, 2018; pp. 185-201.

65. Gnatiuk, O. The renaming of streets in post-revolutionary Ukraine: Regional strategies to construct a new national identity. Acta Univ. Carolinae Geogr. 2018, 53, 119-136. [CrossRef]

66. Light, D. Tourism and toponymy: Commodifying and consuming place names. Tourism Geogr. 2014, 16, 141-156. [CrossRef]

67. Perono Cacciafoco, F. HG2093 Week 2: Toponyms and Toponymic Classification. Available online: https://ntulearn.ntu.edu.sg/ (accessed on 20 January 2021).

68. Mamvura, Z. 'Where art thou?': Ethnocracy, toponymic silence, and toponymic subjugation in the Harare commemorative landscapes during the Mugabe era (1980-2017). Urban Forum 2020, 32, 17-31. [CrossRef]

69. Madden, D.J. Pushed off the map: Toponymy and the politics of place in New York City. Urban Stud. 2018, 55, 1599-1614. [CrossRef]

70. Perono Cacciafoco, F. HG2093 Week 3: Disputed Place Names and Sequent Occupance. Available online: https://ntulearn.ntu. edu.sg/ (accessed on 21 January 2021).

71. Cavallaro, F.; Perono Cacciafoco, F.; Tan, Z.X. Sequent Occupance and toponymy in Singapore: The diachronic and synchronic development of urban place names. Urban Sci. 2019, 3, 98. [CrossRef]

72. Kratochvíl, F.; Delpada, B.; Perono Cacciafoco, F. Abui landscape names: Origin and functions. Onoma 2016, 51, 75-111. [CrossRef] [PubMed]

73. Lim, S.T.G.; Perono Cacciafoco, F. Plants and place names: An Abui case study. Rev. Hist. Geogr. Toponomast. 2020, XV, 121-142.

74. Perono Cacciafoco, F. HG2093 Week 1: An Introduction to Toponymy and Toponomastics. Available online: https://ntulearn.ntu. edu.sg/ (accessed on 21 January 2021).

75. Jericó, M.C.; Baguer, J.P.; Altarriba, L.E. Do the Spanish LOMCE curricula on secondary education improve the preceding educative laws with respect to landscape teaching? Didáctica Geogr. 2017, 18, 251-255. 